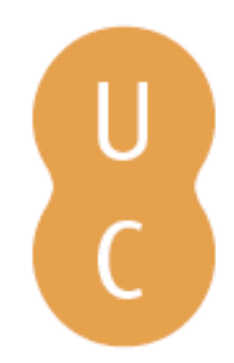

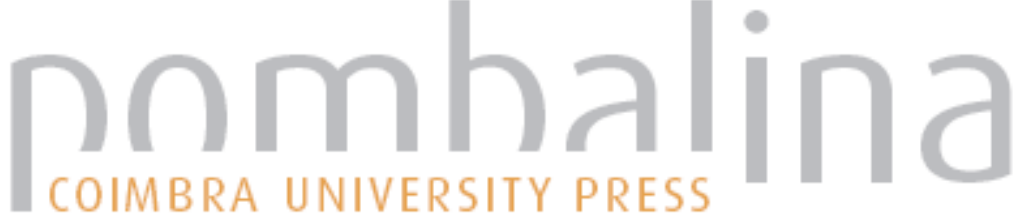

\section{Investigation of the trends in rainfall data in Slovakia, Portugal and Libya}
Autor(es): $\quad$ Zeleáková, Martina; Purcz, Pavol; Portela, Maria Manuela; Hlavatá, Helena; Gargar, Ibrahim

Publicado por: Imprensa da Universidade de Coimbra; RISCOS - Associação

URL persistente: Portuguesa de Riscos, Prevenção e Segurança

DOI: $\quad$ DOI:http://dx.doi.org/10.14195/978-989-96253-3-4_44

Accessed : $\quad$ 26-Apr-2023 01:38:14

A navegação consulta e descarregamento dos títulos inseridos nas Bibliotecas Digitais UC Digitalis, UC Pombalina e UC Impactum, pressupõem a aceitação plena e sem reservas dos Termos e Condições de Uso destas Bibliotecas Digitais, disponíveis em https://digitalis.uc.pt/pt-pt/termos.

Conforme exposto nos referidos Termos e Condições de Uso, o descarregamento de títulos de acesso restrito requer uma licença válida de autorização devendo o utilizador aceder ao(s) documento(s) a partir de um endereço de IP da instituição detentora da supramencionada licença.

Ao utilizador é apenas permitido o descarregamento para uso pessoal, pelo que o emprego do(s) título(s) descarregado(s) para outro fim, designadamente comercial, carece de autorização do respetivo autor ou editor da obra.

Na medida em que todas as obras da UC Digitalis se encontram protegidas pelo Código do Direito de Autor e Direitos Conexos e demais legislação aplicável, toda a cópia, parcial ou total, deste documento, nos casos em que é legalmente admitida, deverá conter ou fazer-se acompanhar por este aviso. 

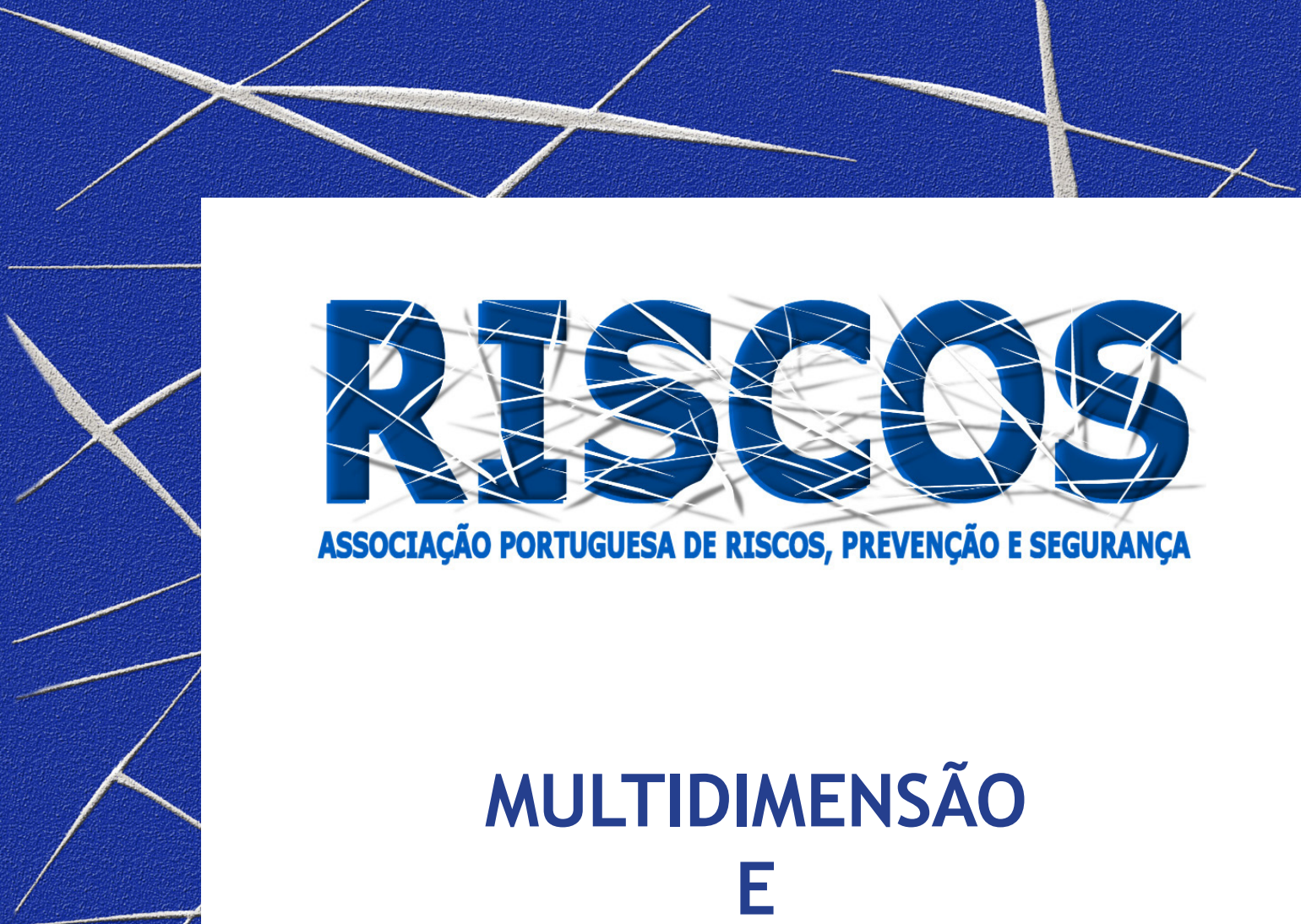

ASSOCIAÇÃO PORTUGUESA DE RISCOS, PREVENCCÃO E SEGURANÇA

MULTIDIMENSÃO

E
TERRITÓRIOS DE RISCO

III Congresso Internacional

I Simpósio Ibero-Americano

VIII Encontro Nacional de Riscos

Guimarães

2014 


\title{
INVESTIGATION OF THE TRENDS IN RAINFALL DATA IN SLOVAKIA, PORTUGAL AND LIBYA
}

\author{
Martina Zeleňáková \\ Department of Environmental Engineering, Faculty of Civil Engineering of the Technical University of Košice \\ martina.zelenakova@tuke.sk \\ Pavol Purcz \\ Department of Mathematics, Faculty of Civil Engineering of the Technical University of Košice \\ pavol.purcz@tuke.sk \\ Maria Manuela Portela \\ Department of Civil Engineering, Architecture and Geo Resources, Technical University of Lisbon \\ maria.manuela.portela@ist.utl.pt \\ Helena Hlavatá \\ Slovak Hydrometeorological Institute \\ helena.hlavata@shmu.sk \\ Ibrahim Gargar \\ Department of Environmental Engineering, Faculty of Civil Engineering of the Technical University of Košice
}

\begin{abstract}
One of the goals of the hydrological risk assessment is to reduce the impacts of droughts and floods. The objective of study is to investigate rainfall trends in climatic stations in Slovakia, Portugal and Libya. Annual and seasonal precipitation trends were detected by the Mann-Kendall non-parametric statistical test. The annual rainfall series at the Portuguese and Libyan climatic stations show mostly downwards trends (decreasing rainfall) while the series at the Slovak climatic stations show upwards trends (increasing rainfall). The results are in accordance with the IPCC forecasts. They also indicate that the variability of extreme rainfall and the climate uncertainty are greater in recent times.
\end{abstract}

Keywords: precipitation; trend; Mann-Kendall; climatic change.

\section{Introduction}

Observations show that changes are occurring in the amount, intensity, frequency and type of precipitation. These aspects of precipitation generally exhibit large natural variability, and $\mathrm{El}$ Niño and changes in atmospheric circulation patterns such as the North Atlantic Oscillation have a substantial influence. Pronounced long-term trends from 1900 to 2005 have been observed in precipitation amount in some places: significantly wetter in eastern North and South America, northern Europe and northern and central Asia, but drier in the Sahel, southern Africa, the Mediterranean and southern Asia. More precipitation now falls as rain rather than snow in northern regions. Widespread increases in heavy precipitation events have been observed, even in places where total amounts have decreased. These changes are associated with increased water vapour in the atmosphere arising from the warming of the world's oceans, especially at lower latitudes. There are also increases in some regions in the occurrences of both droughts and floods (IPCC, 2007).

In recent years, a number of studies have been published focusing on the evolution of precipitation, drought conditions and moisture availability in the Mediterranean during the 20th century (e.g., Paulig and Paeth, 2006; Lopez-Moreno et al., 2009; Sousa et al., 2011). El Kenawy et al. (2009) investigated spatial variability of temperature trends over Libya in the second half of the 20th century. One of the most extensive analyses of the spatial and temporal patterns of precipitation in Portugal was developed by Portela et al. (2013), Santos et al. 
(2010), Santos and Portela (2008). Trends in precipitation in Libya were studied in Zeleňáková et al. (2013), Zeleňáková et al. (2014).

The detection of trends in meteorological data, in particular rainfall is essential for the assessment of the impacts of climate variability and change on the water resources of a region. This paper deals with the research of monthly precipitation trends in climatic stations in Libya and Slovakia in different time series - annual, half year, seasons. The Mann-Kendall test is example of non-parametric tests and was applied to detect trends and to assess the significance of the trends in the time series in presented paper.

\section{Material and methods}

Monthly rainfall data recorded at four stations in eastern Slovakia provided by Slovak Hydrometeorological Institute with length from 1980 to 2010 were collected for this study. In Portugal monthly rainfall data from 1910 to 2004 at four stations were used for statistical trend analysis. In Libya four stations and 40 years of data observation operated by Libya's Meteorological Service from 1970 to 2010 were set up to study precipitation trends. The evaluation was done for the time period from November to October in Slovakia and Libya and from October to September in Portugal. We have selected four stations in each country exactly with the altitude around $400 \mathrm{~m}$ asl. to exclude the effect of altitude to precipitation trends. In Libya: Ghadames, Sabha, Al Kufrah are situated in the desert (in the south) and Shahat is situated near the seaside.

The Mann-Kendall (MK) test (Kendall, 1975; Mann 1945) is a rank-based nonparametric test for assessing the significance of a trend, and has been widely used in hydroclimatological trend detection in many studies (Burn and Elnur, 2002). The significance level is chosen as $a=0.05$ and $Z_{\alpha / 2}$ is the value of normal distribution function, in this case $Z_{\alpha / 2}=1.95996$. Hypothesis $H_{0}$ - no trend is if $\left(Z<Z_{\alpha / 2}\right)$ and $H_{1}$ - there is a trend if $Z>Z_{\alpha / 2}$. The magnitude of the trend was determined using Sen 's estimator (Sen, 1968). A positive value indicates an upward (increasing) trend and a negative value indicates a downward (decreasing) trend in the time series.

\section{Results}

The results of trend analysis for the precipitation data are discussed in the following. Results of precipitation analysis are presented for annual, half year, seasons in Table I for climatic stations in Slovakia, in Table II for stations in Portugal and in Table III for climatic stations in Libya. Two signs (++ or --) indicate statistical significance at $95 \%$ confidence level as per the Mann-Kendall test (+ for increasing and - for decreasing). 
Table I Sen `s estimator for annual, half year and seasons trends in precipitation in Slovakia

\begin{tabular}{|c|c|c|c|c|c|c|c|c|}
\hline \multirow{2}{*}{ Station } & \multirow{2}{*}{ Altitude } & \multirow{2}{*}{ Annual } & \multicolumn{2}{|c|}{ Half year } & \multicolumn{4}{|c|}{ Seasons } \\
\cline { 3 - 9 } & & XI-X & XI-IV & V-X & XI-I & II-IV & V-VII & VIII-X \\
\hline Spišská Nová Ves & 456 & ++ & + & + & + & + & ++ & + \\
\hline Spišské Vlachy & 380 & + & + & ++ & + & + & ++ & + \\
\hline Mníšek nad Hnilcom & 410 & ++ & ++ & ++ & + & + & ++ & + \\
\hline Jakubovany & 410 & + & + & + & + & + & + & + \\
\hline
\end{tabular}

Table II Sen `s estimator for annual, half year and seasons trends in precipitation in Portugal

\begin{tabular}{|c|c|c|c|c|c|c|c|c|}
\hline \multirow{2}{*}{ Station } & \multirow{2}{*}{ Altitude } & \multirow{2}{*}{$\frac{\text { Annual }}{\text { X-IX }}$} & \multicolumn{2}{|c|}{ Half year } & \multicolumn{4}{|c|}{ Seasons } \\
\hline & & & $X-I I I$ & IV-IX & $X-X I I$ & $|-| I \mid$ & IV-VI & VII-IX \\
\hline Chaves & 350 & - & - & 0 & + & -- & - & + \\
\hline Sao Miguel da Acha & 376 & -- & -- & 0 & - & $-\cdot$ & - & 0 \\
\hline Mosteiro de Cabril & 389 & - & -- & + & - & -- & - & 0 \\
\hline $\begin{array}{c}\text { Torre de Dona } \\
\text { Chama }\end{array}$ & 359 & 0 & - & + & + & $-\cdot$ & - & + \\
\hline
\end{tabular}

Table III Sen `s estimator for annual, half year and seasons trends in precipitation in Libya

\begin{tabular}{|c|c|c|c|c|c|c|c|c|}
\hline \multirow{2}{*}{ Station } & & Annual & \multicolumn{2}{|c|}{ Half year } & \multicolumn{4}{|c|}{ Seasons } \\
\cline { 2 - 9 } & & XI-X & XI-IV & V-X & XI-I & II-IV & V-VII & VIII-X \\
\hline Ghadames & 330 & -- & -- & -0 & -0 & -- & -0 & -0 \\
\hline Sabha & 420 & +0 & +0 & +0 & -0 & -0 & +0 & +0 \\
\hline Shahat & 531 & ++ & ++ & ++ & ++ & ++ & +0 & ++ \\
\hline Al Kufrah & 436 & -0 & -0 & -0 & -0 & -0 & -0 & -0 \\
\hline
\end{tabular}

Trend analysis of rainfall series in Slovakia shows the mainly positive values. Significant positive trends are mainly is in station Mnišek nad Hnilcom which is situated in southern part of study area. The trend slope is increase of annual precipitation e.g. in Mníšek nad Hnilcom it is 0.057 mm/year (Zeleňáková et al., 2014). Significant positive trend is in stations - Spišská Nová Ves, Spišské Vlachy, Mnišek nad Hnilcom mainly in summer, in winter the trend is slighty decreasing. The trend is opposite in Portugal climatic stations. All evaluated stations present mainly decreasing trend in rainfall amount, significant in spring. Slightly positive trend is detected in station Torre de Dona Chama.

Rainfall data series did not show any clear trend for the Libya's stations. Rainfall trends show large variability. It depends upon many factors, as was said, namely latitude, altitude, and distance from the sea. Declining trend in rainfall presents desert stations: Ghadames and Al Kufrah. The Shahat station presents increasing trend.

\section{Conclusion}

The objective of this study was to investigate precipitation trends in chosen climatic stations in Slovakia, Portugal and Libya. We investigated 4 climatic stations in different time series. 
Almost all the gauging stations in Slovakia show positive trend of annual precipitation. Annual, half year and seasons trends in precipitation in Portugal show decreasing trend. It proved pronounced long-term trends from Intergovernmental Panel for Climatic Changes from 1900 to 2005 that have been observed in precipitation amount in some places: wetter in northern Europe (Slovakia), but drier in the Mediterranean. The exception is Shahat station in Libya in which the precipitation trends are positive. The influence of other factor such as exposition of the station etc. is probable. The high risk of drought is presented in western and souther part of Libya.

\section{Acknowledgments}

This work has been supported by the Slovak Research and Development Agency SK-PT-0001-12.

\section{Bibliography}

Burn, D. H., Hag Elnur, M. A. (2002) - Detection of hydrologic trends and variability. Journal of Hydrology, 255, p. 107-122.

El Kenawy, A. M., López-Moreno, J. I., Vincente-Serrano, S. M., Mekld, M. S. (2009) -Temperature trends in Libya over the second half of the 20th century. Theoretical and Applied Climatology. 98 (1-2).

Climate Change: Working Group I. (2007) - The Physical Science Basis. How is Precipitation Changing? http://www.ipcc.ch/publications_and_data/ar4/wg1/en/faq-3-2.html

Kendall, M.G. (1975) - Rank Correlation Measures. Charles Griffin, London.

Mann, H.B. (1945) - Non-parametric tests against trend. Econometrica 13, p. 245-259.

Lopez-Moreno, J., Vicente-Serrano, S., Gimeno, L., Nieto, R. (2009) - Stability of the seasonal distribution of precipitation in the Mediterranean region: Observations since 1950 and projections for the 21st century, Geophys. Res. Lett., 36, 10703.

Pauling, A., Paeth, H. (2006) - On the variability of return periods of European winter precipitation extremes over the last five centuries. Clim. Past Discuss., 2, p. 157-189.

Portela, M. M., Santos, J. F., Quintela, A.C., Vaz C. (2009) - Trends in hydrologic time series In: River Basin Management 5: Southampton: Wessex Institute of Technology. p. 185-195.

Santos, J. F., Pulido-Calvo I., Portela M. M. (2010) - Spatial and temporal variability of droughts in Portugal, Water Resour. Res., 46.

Santos J. F., Portela M. M. (2008) - Quantificação de tendências em séries de precipitação mensal e anual em Portugal Continental, paper presented at Seminário Ibero-Americano sobre Sistemas de Abastecimento Urbano SEREA, Lisbon, Portugal, 2008

Sen, P. K. (1968) - Estimates of the regression coefficient based on Kendall's tau. Journal of the American Statistical Association 63, p. 1379-1389.

Sousa, P. M., Trigo, R. M., Aizpurua, P., Nieto, R., Gimeno, L., Garcia-Herrera, R. (2011) - Trends and extremes of drought indices throughout the 20th century in the Mediterranean. Nat. Hazards Earth Syst. Sci., 11, p. 33-51.

Zeleňáková, M., Purcz, P., Gargar, I., Hlavatá, H. (2013) - Comparison of precipitation trends in Libya and Slovakia In: River Basin Management 6, Southampton: Wessex Institute of Technology. p. 365-374.

Zeleňáková, M., Purcz, P., Gargar, I., Hlavatá, H. (2014) - Research of monthly precipitation trends in Libya and Slovakia, In: Recent Advances in Environmental Science and Geoscience, Sofia: EUROPMENT, 2014, p. $46-50$. 